\title{
Çocukları İlkokula Başlayan Ebeveynlerin Okula Hazırbulunuşluk ve Okula Uyum Süreci Hakkındaki Görüşleri
}

\author{
Dr. Öğr. Üyesi Hatice ÖZASLAN* \\ Ondokuz Mayıs Üniversitesi, Eğitim Fakültesi, Temel Eğitim Bölümü, Samsun / Türkiye, \\ haticedizmanozaslan@yahoo.com, ORCID: 0000-0003-4902-951X
}

Arş. Gör. Dr. Melek BABA-ÖZTÜRK

Ondokuz Mayıs Üniversitesi, Eğitim Fakültesi, Temel Eğitim Bölümü, Samsun / Türkiye, melekbaba87@gmail.com, ORCID: 0000-0003-0515-8782

\section{$\ddot{O} z$}

$\mathrm{Bu}$ araştırmada çocukları ilkokula başlayan ebeveynlerin okula hazırbulunuşluk ve okula uyum süreci hakkındaki görüşlerini belirlemek amaçlanmıştır. Nitel araştırma yöntemlerinden fenomenoloji desenine örnek teşkil eden araştırmaya, 2018-2019 eğitim öğretim yılında çocuğu ilkokula başlamış 20 ebeveyn katılmıştır. Katılımcıların belirlenmesinde amaçlı örnekleme yöntemlerinden homojen örnekleme kullanılmıştır. Araştırma verileri araştırmacılar tarafından geliştirilen yarı yapılandırılmış görüşme formuyla elde edilmiştir. Veriler yüz yüze görüşme tekniğiyle toplanmış ve içerik analizi yoluyla çözümlenmiştir. Araştırma bulguları, okula hazırbulunuşluk ve okula uyum süreci olmak üzere iki ana tema altında toplanmıştır. Araştırma sonuçları ebeveynlerin hazırbulunuşluğu farklı gelişim alanlarına vurgu yapacak şekilde tanımladıklarını ve çoğunluğunun sosyal-duygusal gelişim alanını öne çıkaran açıklamalar yaptıklarını ortaya koymuştur. Ebeveynler ilkokula başlayacak çocukların özellikleri hakkında beş ayrı kategoride toplanan çok sayıda beceri ve yeterlilikten söz etmekle

* Sorumlu Yazar. Tel: +90 5443514064 | Araştırma Makalesi.

Makale Tarih Bilgisi. Gönderim: 06.02.2021, Kabûl: 09.04.2021, Erken Görünüm: 10.02.2022, Basım: Haziran, 2022

(C) 2022. Kalem Eğitim ve Sağlık Hizmetleri Vakfı. Bütün Hakları Saklıdır. ISSN: 2146-5606, e-ISSN: 2687-6574. 
birlikte sosyal-duygusal gelişim alanı ile öz bakım becerilerini daha çok vurgulamışlardır. Ebeveynlerin çocuklarının okula uyum süreçleri hakkındaki görüşleri incelendiğinde ise bu süreçte çocuklarında olumlu ve olumsuz pek çok davranış gözlemlediklerini belirtmişlerdir. Okul yönetimi ve öğretmenlerin çocuklarının okula uyumlarını sağlamaya yönelik farklı çalışmalar yaptıklarından söz etmiş ve bu sürecin sağlıklı atlatılabilmesi için okul-aile iş birliğinin önemini vurgulamışlardır. Elde edilen bulgular literatür ışığında tartışılmış ve çeşitli önerilerde bulunulmuştur.

Anahtar Kelimeler: Okula hazırbulunuşluk; Okula uyum; Ebeveyn; İlkokul birinci sınıf öğrencisi; Nitel araştırma.

\title{
The Opinions of Parents Regarding the School
}

\section{Readiness and School Adjustment Process of Their Children Who Start Primary School}

\begin{abstract}
In this study, it was aimed to determine the opinions of parents regarding the school readiness and school adjustment process of their children who start primary school. 20 parents whose children started primary school in the 2018-2019 academic year participated in the study, which sets an example for the phenomenology pattern, one of the qualitative research methods. Homogeneous sampling, one of the purposeful sampling methods, was used in determining the participants. Research data were obtained through a semi-structured interview form developed by the researchers. The data were collected using face-to-face interview technique and analyzed by content analysis method. The research findings are presented under two main themes as school readiness and school adjustment process. Research results reveal that parents define readiness in a way that emphasizes different developmental areas and most of them make explanations that emphasize the social-emotional development area. Although the parents talked about the characteristics of the children who will start primary school, many skills and competencies gathered in five separate categories, they emphasized the socialemotional development area and self-care skills more. When the opinions of parents about their children's adaptation to school processes were examined, they stated that they observed many positive and negative behaviors in their children during this process. They mentioned that school management and teachers are doing different activities to ensure their children's adaptation to school and emphasized the importance of school-family cooperation in order to overcome this process in a healthy way. The findings were discussed in the light of the literature and various suggestions were made.
\end{abstract}


Keywords: School readiness; School adjustment; Parent; Primary school first grade student; Qualitative research.

\section{Extended Summary}

\section{Purpose}

Starting school is a different and exciting process as it involves new experiences. Children face an unfamiliar environment, rules, duties, and responsibilities (Erkan, 2011). Starting school is considered a critical developmental task because it plays a crucial role in children's future success and behavior (Entwisle, Alexander and Olsen, 2005). Children who start primary school are expected to establish healthy relationships with their friends and teachers, obey social rules, follow instructions, and develop fundamental academic skills, such as reading-writing and arithmetical operations (Oktay and Unutkan, 2003). Fulfilling these expectations and adjusting to school depends on school readiness. School readiness is defined as developing physical, cognitive, linguistic, social, emotional, and self-care skills to have enough capacity to start school. In other words, school readiness is being ready to fulfill primary school requirements (Özaslan, 2020).

Children who learn about primary school requirements in the preschool period are better at adjusting to primary school. Children who fail to learn how to fulfill those requirements experience low motivation for learning and have a hard time adjusting to school, which results in low academic performance (Oktay, 2018). There is a positive correlation between academic performance and school readiness. Children with low school readiness are likely to have low performance (Brooks-Gunn, Berlin and Fuligni, 2000). School adjustment is a multifaceted concept that also relates to social influences and behavior. School adjustment is closely related to attitudes and emotions towards school, participation in education and academic performance (Yoleri and Tanış, 2014). School adjustment is critical for children. Therefore, those who have difficulties adjusting to school should be supported quickly and correctly. To that end, factors affecting school adjustment should be taken into account (Polat and Atış-Akyol, 2019).

Many factors affect the school adjustment of children who start primary school. Not being ready to start school is one of the greatest causes of adaptation problems, which are exacerbated by numerous domestic factors, such as overdependence on the mother, unrealistic expectations of parents, domestic conflict and death (Gülay-Ogelman and Erten-Sarıkaya, 2013). It is known 
that school adjustment can also be promoted by programs tailored to children's needs, teachers' behaviors and attitudes, and physical and social school environment (Oktay, 2018). Therefore, we should determine parents' views on school readiness and school adjustment to support the school adjustment processes of children who start primary school. We think that results will make contributions to the literature.

\section{Method}

This qualitative study investigated the opinions of parents regarding the school readiness and school adjustment of their children who start primary school. Phenomenology was the research design of choice. The sample consisted of 20 parents from Atakum/Samsun, Turkey. All participants had children who started school in the 2018-2019 academic year. The participants were recruited using homogeneous sampling, which is a purposive sampling method. Data were collected using a semi-structured interview form developed by the researchers. The data were analyzed using content analysis, which is a qualitative analysis method.

\section{Results, Discussion and Conclusion}

The participants emphasized different development areas when defining "school readiness" but most of them referred to the socioemotional area. They noted a number of skills and competencies in five different categories regarding the qualities that children who start primary school should have. However, they mostly focused on socioemotional development and self-care skills. They observed numerous positive or negative behaviors in their children during the 'school adjustment' process. Some of the negative behaviors were wanting his/her mother, not wanting to go to school, not wanting to go to the toilet at school, and feeling anxiety and fear. Some of the positive behaviors were sharing, expressing, communicating, and moving regularly. The participants stated that school administrators and teachers performed art activities and played games with their children to promote school adjustment but did few school orientation activities. The following are recommendations to educators, parents and researchers based on the results:

- Parents should be informed about what "school readiness" is and about qualities that children who start primary school are supposed to have.

- Parents should be informed of and supported for school adjustment.

- The School Adjustment Program implemented by the Ministry of National Education should be tailored to the needs of children and parents. 
Children who start primary school should be trained in school adjustment by experts.

- Schools and parents should cooperate to facilitate and accelerate the 'school adjustment' process of children who start primary school.

\section{Giriş}

Bütün öğretim kademelerinde okula başlamak, değişik ve yeni tecrübeler içerdiğinden heyecanlı bir süreçtir. Çocuk alışık olmadığı bir ortamla, kurallarla, görev ve sorumluluklarla karşı karşıya kalır (Erkan, 2011). Okula başlama, çocuğun gelecekteki başarısı ve davranış kalıpları üzerinde oldukça etkili olabileceğinden çok önemli bir gelişim görevi olarak kabul edilir (Entwisle, Alexander ve Olsen, 2005). İlkokula başlayan çocuktan arkadaşları ve öğretmeniyle sağlıklı ilişkiler kurması, sosyal kurallara uyması, öğretmenin verdiği yönergeleri yerine getirmesi, okuma-yazma ve aritmetik gibi temel akademik becerileri öğrenmesi beklenmektedir (Oktay ve Unutkan, 2003). Çocuğun bu beklentileri yerine getirebilmesi, okula uyum sağlayabilmesi onun okula hazırbulunuşluğuna bağlıdır.

Alanyazın incelendiğinde okula hazırbulunuşluk kavramına yönelik net bir tanım olmadığı, farklı tanımlar bulunduğu görülmektedir. Bu tanımlar incelendiğinde belli kavramlar ve beceriler üzerinde durulduğu anlaşılmaktadır. Forget-Dubois ve arkadaşları (2007) okula hazırbulunuşluğu, çocuğun kolay öğrenmesi ve okula uyum sağlaması için gerekli bilişsel, iletişimsel, davranışsal ve duygusal becerileri içine alan çok yönlü bir kavram olarak tanımlamaktadırlar. Miclea ve Mihalca (2007)'da okula hazırbulunuşluğun çok boyutlu bir kavram olduğunu ve en az üç ögeyi içerdiğini belirtmektedirler. Bunlar; çocukların bilgi ve becerileri, çevrelerinin (aileler, erken eğitim programları ve toplum) erken öğrenmeyi ve gelişimi besleme kapasitesi ile okulun okula yeni başlayan çocukların gelişimini destekleme kapasitesidir. Commodari (2012) okula hazırbulunuşluğun akademik beceriler dışında duyguları kontrol etme, stresle baş edebilme, verilen yönergeleri yerine getirme, sınıftaki görevleri yapabilme, diğer insanlarla iş birliği içinde olabilme ve zengin kelime hazinesine sahip olma gibi ön koşulları da içinde bulundurduğunu ifade etmektedir. Dinç (2013, s.95) ise okula hazır oluşu, çocuğun bütün gelişim alanlarının yanında öğrenme yaklaşımları, kavrama ve genel bilgi açısından çevrenin desteğini alarak kendisinden beklenen seviyeye gelmesi ve buna yönelik gerekli olan bilgi, beceri ve tutumlara sahip olması şeklinde tanımlamaktadır. 
Bütün bu tanımlardan yola çıkıldığında okula hazırbulunuşluğu, büyüme, olgunlaşma ve öğrenme sonucunda çocuğun fiziksel, bilişsel, sosyal, duygusal ve dil gelişimi, öz bakım becerileri alanında belli bir düzeye gelerek ilkokula başlayacak yeterliliğe sahip olması, ilkokulun gereklerini yerine getirmeye hazır olması şeklinde tanımlamak mümkündür (Özaslan, 2020).

İlkokula başlayan çocuğun okula uyum sağlayabilmesi için okul öncesi dönemde ilkokulun gereklerini kazanmış olması gerekir. Bu özelliklerin kazanılmaması sonucunda yaşanacak kırıklıklar, çocuğun öğrenmeye karşı olan isteğini azaltacak, okula uyumu ve dolayısıyla da okuldaki başarısı üzerinde olumsuz etkilere neden olacaktır (Oktay, 2018). Çocuğun okuldaki başarısının onun okula hazırbulunuşluğuyla ilişkili olduğu ve okula hazır olmayan çocukların başarılarının düşük olduğu bilinmektedir (Brooks-Gunn, Berlin ve Fuligni, 2000). Okula uyum, okul başarısının dışında sosyal etki ve sosyal davranışlarla da ilişki içinde olan çok yönlü bir kavramdır. Okula uyum, çocuğun okula yönelik tutumu, yaşadığı duyguları, eğitim sürecindeki katılımı ve akademik başarısı ile ilgilidir (Yoleri ve Tanış, 2014).

Örgün eğitime başlayan bazı çocuklar kolay bir şekilde okula uyum sağlarken, bazı çocuklar ise uyum problemleri yaşamaktadırlar. Ayrıca bu çocukların okula uyum sağlama süresinde de farklılıklar görülmektedir. Bazı çocuklar ilk haftada uyum sağlarken, kimisinin uyum sağlama süreci ayları hatta bir dönemi alabilmektedir. Okula uyum sağlamak, çocuk için çok önemli olduğundan bu konuda sıkıntı yaşayan çocukların hızlı ve doğru bir şekilde desteklenmesi gerekmektedir. Bu destek için çocuğun okula uyumunu etkileyen etmenlerin iyi değerlendirilmesi önemlidir (Polat ve Atış-Akyol, 2019). Çocukların okula uyumlarını etkileyen birçok faktör bulunmaktadır. Çocuğun okula başlamaya hazır olmaması uyum problemlerinde önemli bir yere sahiptir. Ayrıca aile içindeki faktörler de çocuğun okula uyumunda önemli bir yer teşkil eder. Çocuğun anneye aşırı bağımlı olması, ailenin çocuğun sahip olduğu gelişim özelliklerinin üstünde olan beklentileri, aile içinde yaşanan çatışmalar ve ölümler gibi birçok durum aileye yönelik faktörlerdir (GülayOgelman ve Erten-Sarıkaya, 2013). Çocuğun okula uyumlu bir başlangıç yapabilmesinde hazırlanan programların, öğretmenlerin davranış ve yaklaşımlarının, okulun fiziksel ve sosyal ortamının büyük etkisi vardır (Oktay, 2018). Birleşmiş Milletler Çocuklara Yardım Fonu (UNICEF, 2012) çocuğun okula hazır olmasını ailenin, çocuğun ve okulun hazır olma durumunun etkilediğini 
ve geçiş sürecinin bu kapsamda değerlendirilmesinin önemli olduğunu vurgulamaktadır. Çocukların farklı özelliklerinin dikkate alınarak onlara uygun yaratıcı ortamların sağlanması ve okul aile iş birliğinin aktif bir şekilde yapılmasının gerekli olduğunu belirtmektedir. Çocukların okula uyumlarını çocuk, aile ve öğretmen kaynaklı birçok faktör etkilemektedir (Bağçeli-Kahraman, 2020). Baughan (2012) ilkokula geçiş dönemindeki çocukların okula uyumlarını incelediği çalışma sonucunda ebeveynin çocuğun okul hayatına katılımı ve memnuniyetinin okula uyum sürecinin en önemli yordayıcılarından olduğunu ortaya koymuştur. Alanyazın incelendiğinde birinci sınıf ebeveynlerinin okula hazırbulunuşluk (Ayten, 2019; Koçyiğit ve Saban, 2014; Ülkü, 2007) ve okula uyumla (Bay ve Şimşek-Çetin, 2014; Çeliktürk-Sezgin, 2020; Iş1koğlu-Erdoğan ve Şimşek, 2014; Teymurlu, 2019; Yazıc1, Nazik-Kumbasar ve Akman, 2017) ilgili görüşlerini ele alan sınırlı sayıda çalışma olduğu görülmüştür. Bununla birlikte okula hazırbulunuşluk ve okula uyum sürecinin birlikte değerlendirildiği herhangi bir çalışmaya ise rastlanılmamıştır. Bu bağlamda ebeveynlerin konuyla ilgili görüşlerinin belirlenmesinin çocukların okula uyum süreçlerini kolaylaştıracak düzenlemelerin yapılabilmesi açısından önemli olduğu ve alanyazına katkı sağlayacağı düşünülmektedir. Araştırmada bu düşünceden hareketle şu sorulara yanıt aranmıştır:

1. Çocuğu ilkokula başlayan ebeveynlerin okula hazırbulunuşluk hakkındaki görüssleri nelerdir?

2. Çocuğu ilkokula başlayan ebeveynlerin okula uyum süreçleri hakkındaki görüşleri nelerdir?

\section{Yöntem}

Bu bölümde araştırma deseni, katılımcılar, veri toplama aracı, geçerlik güvenirlik ve verilerin analizi ile ilgili ayrıntılı bilgiler verilmiştir.

\section{Araştırma Deseni}

Çocukları ilkokula başlayan ebeveynlerin okula hazırbulunuşluk ve okula uyum süreci hakkındaki görüşlerinin belirlenmeye çalışıldığı bu araştırmada nitel araştırma desenlerinden fenomenoloji kullanılmıştır. Eğitimde en yaygın kullanılan nitel araştırma yöntemlerinden biri olan fenomonoloji, yaşadığımız dünyada olaylar, deneyimler, yönelimler, algılar ve kavramlar gibi farklı şekillerde karşımıza çıkan, farkında olduğumuz ancak derinlemesine bir anlayışa sahip olmadığımız olgulara odaklanmaktadır (Yıldırım ve Şimşek, 2011). Bu doğrultuda mevcut araştırmada, çocuğu ilkokula başlayan ebeveynlerin okula hazırbulunuşluk kavramını nasıl algıladıkları ve çocuklarının 
okula uyum süreçlarini nasıl değerlendirdikleri belirlenmek istendiğinden fenomonoloji tercih edilmiştir.

\section{Katılımcilar}

Araştırmanın katılımcılarını Samsun ili Atakum ilçesinde yaşayan ve çocuğu 2018-2019 eğitim öğretim yılı güz döneminde ilkokul birinci sınıfa başlamış 20 ebeveyn oluşturmaktadır. Katılımcılar belirlenirken amaçlı örnekleme yöntemlerinden homojen örnekleme kullanılmıştır. Amaçlı örnekleme, nitel araştırma geleneği içinde ortaya çıkan ve zengin bilgiler barındırdığı düşünülen durumların derinlemesine çalışılmasına imkân sağlayan bir örnekleme yöntemidir (Yıldırım ve Şimşek, 2011). Homojen (benzeşik) örnekleme ise amaçlı örnekleme yöntemleri arasında yer alan, küçük ve benzeşik bir örneklem oluşturarak belirgin bir alt grubu tanımlamayı amaçlayan bir yöntemdir. Bu bağlamda katılımcılar seçilirken ebeveynlerin öğrenim durumu açısından benzer özellikler göstermelerine dikkat edilmiştir. Katılımcılara ilişkin bilgilere Tablo 1'de yer verilmiştir.

Tablo 1. Katılımcılara İlişkin Bilgiler

\begin{tabular}{cccccc}
\hline Katılımcı & Cinsiyet & Yaş & $\begin{array}{c}\text { Çocuk } \\
\text { Sayısı }\end{array}$ & $\begin{array}{c}\text { Çocuğun } \\
\text { Cinsiyeti }\end{array}$ & $\begin{array}{c}\text { Cocuğun Yaşı } \\
\text { (ay olarak) }\end{array}$ \\
\hline E1 & Kadın & 39 & 2 & Erkek & 74 \\
E2 & Kadın & 38 & 2 & Kız & 75 \\
E3 & Kadın & 29 & 2 & Kız & 72 \\
E4 & Kadın & 32 & 2 & Erkek & 84 \\
E5 & Erkek & 36 & 1 & Kız & 82 \\
E6 & Kadın & 42 & 2 & Erkek & 80 \\
E7 & Kadın & 35 & 2 & K1z & 78 \\
E8 & Kadın & 32 & 2 & K1z & 74 \\
E9 & Kadın & 37 & 2 & Erkek & 72 \\
E10 & Kadın & 40 & 2 & K1z & 72 \\
E11 & Kadın & 40 & 2 & K1z & 82 \\
E12 & Kadın & 35 & 1 & K1z & 74 \\
E13 & Erkek & 38 & 3 & Erkek & 70 \\
E14 & Kadın & 36 & 2 & K1z & 79 \\
E15 & Kadın & 32 & 2 & Erkek & 81 \\
E16 & Kadın & 36 & 2 & K1z & 82 \\
E17 & Kadın & 37 & 1 & K1z & 80 \\
E18 & Kadın & 42 & 3 & K1z & 82 \\
E19 & Kadın & 40 & 2 & K1z & 78 \\
E20 & Kadın & 36 & 2 & K1z & 74 \\
\hline
\end{tabular}

Tablo 1 incelendiğinde araştırmaya katılan ebeveynlerden 18'inin ka- 
dın 2'sinin erkek olduğu, yaş aralığının 29 ile 42 arasında değiştiği, çoğunlukla 2 çocuk sahibi oldukları görülmektedir. Araştırmaya dâhil edilen ebeveynlerin tamamı ise üniversite mezunu olup 6's1 erkek, 14'ü de kız çocuğa sahiptir.

\section{Verilerin Toplanması ve Analizi}

Veriler, araştırmacılar tarafından hazırlanan yarı yapılandırılmış görüşme formu yardımıyla toplanmıştır. Yarı yapılandırılmış görüşme formları, araştırmacıların süreç içerisinde ek sorular sormasına imkân sağladığından derinlemesine bilgi edinimini kolaylaştırmakta, bu da nitel araştırmalarda sıklıkla tercih edilen bir yöntem olmasını sağlamaktadır. Araştırmada görüşme formu oluşturulurken öncelikle kapsamlı bir alanyazın taraması yapılmış ve konuya ilişkin kavramsal çerçeve belirlenmiştir. Daha sonra 10 soruluk taslak bir form oluşturulmuş ve oluşturulan form, konu alanı uzmanı üç öğretim üyesi tarafından değerlendirilmiştir. Yapılan bu değerlendirme neticesinde taslak formdaki soru sayısı ondan beşe düşürülmüş ve form bu şekliyle iki ebeveyne uygulanmıştır. Uygulama sonrasında soruların anlaşılırlığ netleştirilip forma nihai şekli verilmiştir. Yarı yapılandırılmış görüşme formunda katılımcılara aşağıda belirtilen beş açık uçlu soru sorulmuştur:

1. Sizce okula hazırbulunuşluk nedir?

2. Sizce ilkokula başlayacak çocuk hangi özelliklere sahip olmalıdır?

3. Okula uyum sürecinde çocuğunuzda nasıl davranışlar gözlediniz?

4. Okula uyum sürecinde okul yönetimi ve öğretmen ne tür çalışmalar yaptı?

5. Okula uyum sürecinin sağlıklı atlatılabilmesi için önerileriniz nelerdir?

Görüşmeler ebeveynler ve araştırmacılar tarafından belirlenen ortak bir gün ve saatte, yine birlikte karar verilen bir mekânda gerçekleştirilmiştir. Her bir görüşme ortalama 30 dakika sürmüş ve görüşmeler, veri kaybını en aza indirmek amacıyla ses kayıt cihazı ile kayıt altına alınmıştır. Kayıt öncesinde katılımcılardan gerekli izinler alınmıştır. Görüşmelerden elde edilen veriler, içerik analizi yöntemiyle analiz edilmiştir. Bunun için öncelikle verilerin bilgisayar ortamına yazılı olarak aktarımı sağlanmış, ardından kontrolü yapılarak analize hazır hâle getirilmiştir. Verilerin analizinde dört aşamalı içerik analizi süreci takip edilmiştir (Yıldırım ve Şimşek, 2011). Bu doğrultuda ilk olarak elde edilen bütün veriler ayrıntılı bir şekilde gözden geçirilip benzer ifadeler kodlanmıştır. Daha sonra kodları temsil eden temalar bulunmuş, son aşamada 
da ulaşılan kod ve temalar düzenlenerek bulgular tanımlanmış ve yorumlanmıştır.

\section{Araştırmanın Geçerlik ve Güvenirliği}

Geçerlik ve güvenirlik, türüne bakılmaksızın bir araştırmanın kavramsal çerçevesinin oluşturulması, verilerinin toplanması, analiz edilmesi ve yorumlanması ile bulgularının sunulması aşamalarını ilgilendiren ve araştırmac1ları gerçekçi sonuçlar elde etmeleri, geçerli ve güvenilir bilgi üretmeleri noktasında destekleyen önemli kilometre taşlarındandır (Merriam, 2013). Araştırmada geçerliğin sağlanmasında inandırıcılık ve aktarılabilirlik, güvenirliğin sağlanmasında ise tutarlılık incelemesi stratejilerine başvurulmuştur. Aşağıda bu kapsamda yapılan işlemler detaylı olarak açıklanmıştır:

\section{İnandırıcılık}

İnandırıcılık, araştırma sürecinin ve sonuçlarının farklı araştırmacılar tarafından da teyit edilebilirliğidir (Yıldırım ve Şimşek, 2011). Mevcut araştırmada inandırıcılığın sağlanması için çeşitleme ile katılımcı teyidi stratejileri kullanılmıştır. Alanyazında çeşitleme, iç geçerliği artırmanın en iyi yollarından biri olarak ifade edilmekte ve yöntem, kuram, kaynak ve araştırmaci/analizci olmak üzere dört farklı türde çeşitlemeden söz edilmektedir. Bu araştırmada araştırmacı/analizci çeşitlemesi kullanılmış ve elde edilen veriler, çalışmanın yazarları tarafından birbirlerinden bağımsız şekilde analiz edilmiştir. Ayrıca araştırmada katılımcı teyidi stratejisi de kullanılmıştır. Bu kapsamda veriler yazılı hâle getirildikten sonra katılımcılara sunulmuş ve cevaplarını kontrol etmeleri istenmiştir. Ayrıca eklemek ya da çıkarmak istedikleri herhangi bir nokta olup olmadığı da sorularak gerekli düzenlemeleri yapabilecekleri belirtilmiştir.

\section{Aktarılabilirlik}

Genelleme kavramının nitel araştırmadaki karşılığı olan aktarılabilirlik, elde edilen sonuçların benzer ortamlara ne derece transfer edilebileceğiyle ilgilenmektedir. Mevcut araştırmada aktarılabilirliğin sağlanması için ayrıntılı betimleme ve amaçlı örnekleme stratejileri kullanılmıştır. Bu doğrultuda ebeveynlerden elde edilen veriler doğrudan alıntılarla desteklenerek okuyucuya sunulmuştur. Ayrıca çalışma grubu oluşturulurken amaçlı örnekleme yöntemlerinden homojen örnekleme kullanılmış ve öğrenim durumu açısından benzeşik bir örneklem oluşturularak ebeveynlerin okula hazırbunuşluk kavramını nasıl algıladıkları ve çocuklarının okula uyum sürecini nasıl deneyimledikleri belirlenmeye çalışılmıştır. 


\section{Tutarlılık İncelemesi}

Tutarlılık incelemesi, araştırmacının araştırma sürecinde yaptığı bütün işlemlerin denetlenmesini, araştırmaya dışarıdan bir gözle bakılmasını gerektiren bir stratejidir. Bu doğrultuda okula hazırbulunuşluk ve okula uyum konusunda çalışmalar yapmış olan iki öğretim üyesinden araştırma sürecini detaylı biçimde değerlendirmeleri istenmiştir. Yapılan değerlendirmeler sonucunda araştırma sürecinin (kavramsal çerçevenin oluşturulması, verilerin toplanması, kodlanması ve kavramsal çerçeveyle uyumu, verilerin sonuçlarla ilişkisi) kendi içinde tutarlı bir yapı gösterdiği tespit edilmiştir.

\section{Bulgular}

Ebeveynlerle yapılan görüşmelerden yola çıkarak oluşturulan bu bölümde ebeveynlerin okula hazırbulunuşluk ve okula uyum konusundaki görüşleri derinlemesine incelenmiş ve elde edilen bulgular araştırma soruları doğrultusunda analiz edilerek okula hazırbulunuşluk ve okula uyum süreci olarak iki ana tema altında sunulmuştur.

\section{Okula Hazırbulunuşluk}

Bu başlık altında ebeveynlerin okula hazırbulunuşluğun tanımı ve ilkokula başlayacak çocuğun sahip olması gereken özelliklere ilişkin görüşlerine ait bulgular sunulmuştur.

\section{Okula Hazırbulunuşluğun Tanımı}

Ebeveynlerin okula hazırbulunuşluğun tanımına ilişkin verdikleri cevaplar incelendiğinde okula hazırbulunuşluğu farklı gelişim alanlarına vurgu yapacak şekilde tanımladıkları ve çoğunluğunun sosyal duygusal alana atıfta bulundukları görülmüştür. İki ebeveyn ise okula hazırbulunuşluğu çocukların öğrenmeye karşı istekli ve ilgili olması şeklinde açıklamışlardır. Bu doğrultuda ebeveyn görüşlerine aşağıda yer verilmiştir:

"Çocuğun sosyal ortama alışması, toplum kurallarını ögrenmesi, toplum içinde kendini ifade edebilmesi, kalem kullanmayı ögrenmesi." (E10)

"Okula hazırbulunuşluk, çocuğun okula uyum sağlayabilmesi için sosyal duygusal, zihinsel ve fiziksel alanlarınin gelişmesi." (E4)

"Çocuğun uygun fiziksel ve psikomotor gelişime sahip olması, çocuğun boyu, iskelet vb. kas gelişimi, el becerileri, ince motor geliş̧imi, el göz koordinasyonu yönünden okula başlamaya hazır olmasıdır." (E8)

"Çocuğun iç dünyasında yaşadığı oyun, ilgi, arkadaşllk edinme duygularının gelişserek ikili iletişsime hazır hâle gelmesi, kendi sorumluluğunu 
taşıyabilmesidir.” (E11)

“Okula hazırbulunuşluk çocuğun okula gitmek istemesi, öğretmeninin ve arkadaşlarının olabileceğini bilmesi, okuma-yazma isteğinin olmasidır." (E7)

\section{İlkokula Başlayacak Çocuğun Sahip Olması Gereken Özellikler}

İlkokula başlayacak çocuğun sahip olması gereken özellikler, alanyazın ve okul öncesi eğitim programı (MEB, 2013) dikkate alınarak bilişsel, dil, sosyal ve duygusal, fiziksel-motor gelişim ve öz bakım becerileri temaları altında toplanmıştır. Bu doğrultuda ebeveyn görüşlerine Tablo 2'de yer verilmiştir.

Tablo 2. İlkokula Başlayacak Çocuğun Sahip Olması Gereken Özellikler

\begin{tabular}{|c|c|}
\hline Tema & Kod \\
\hline \multirow{11}{*}{ Sosyal ve duygusal gelişim } & Öz güveni gelişmiş olmalı \\
\hline & Kurallara uyabilmeli \\
\hline & Anne ve babadan ayrı kalabilmeli \\
\hline & Sorumluluk duygusu olmalı \\
\hline & Arkadaşlık kurabilmeli \\
\hline & Arkadaşlarıyla iyi geçinebilmeli \\
\hline & Okula gitmeye istekli olmalı \\
\hline & Sosyal olmal \\
\hline & Paylassmayı bilmeli \\
\hline & Büyüklerine saygilı olmalı \\
\hline & Ortama uyum sağlayabilmeli \\
\hline \multirow[t]{6}{*}{ Öz bakım becerileri } & Tuvalet ihtiyacını kendi başına karşılayabilmeli \\
\hline & Kendi temizliğini yapabilmeli \\
\hline & Tuvalet alışkanlığı kazanmış olmalı \\
\hline & Kendi başına kıyafetlerini giyebilmeli \\
\hline & Kendi başına yemek yiyebilmeli \\
\hline & Kişisel bakımını yapabilmeli \\
\hline \multirow[t]{7}{*}{ Fiziksel ve motor gelişim } & Yaşına uygun bedensel gelişime sahip olmalı \\
\hline & Kalem tutabilmeli \\
\hline & Kesme yapıştırma yapabilmeli \\
\hline & Küçük kasları gelişmiş olmalı \\
\hline & El becerileri gelişmiş olmalı \\
\hline & El kol kaslarını kullanabilmeli \\
\hline & Fiziksel açıdan sağlıklı olmalı \\
\hline \multirow[t]{7}{*}{ Bilişsel gelişim } & Öğrenmeye açık olmalı \\
\hline & Alg1 yeteneği gelişmiş olmalı \\
\hline & Okul ile ilgili bilgiye sahip olmalı \\
\hline & Okula gidiş amacını bilmeli \\
\hline & Anlatılanı anlayabilmeli \\
\hline & Dikkatini toparlayabilmeli \\
\hline & Yönergelere uyabilmeli \\
\hline \multirow{3}{*}{ Dil gelişimi } & Kendini ifade edebilmeli \\
\hline & İletişim becerilerine sahip olmalı \\
\hline & Yassina uygun dil gelisimi göstermeli \\
\hline
\end{tabular}


"İlkokula başlayacak çocuk hangi özelliklere sahip olmalıdır?" araştırma sorusuna verilen yanıtlar incelendiğinde ebeveynlerin bu konuda çok sayıda özellik ve beceri ifade etmekle birlikte sosyal duygusal gelişim özelliklerini daha çok vurguladıkları belirlenmiştir. Kodlar incelendiğinde ebeveynlerin ilkokula başlayacak çocuğun sosyal duygusal özelliklerini tanımlarken en çok öz güven duygusunun ve kurallara uyabilme becerisinin gelişmiş olmasına vurgu yaptıkları görülmüştür. Daha sonra ise anne ve babadan ayrı kalabilme, sorumluluk alabilme, arkadaşlık kurabilme, arkadaşlarıyla iyi geçinebilme, okula gitmeye istekli olma, sosyal olma, paylaşmayı bilme, büyüklerine saygılı olma ve ortama uyum sağlayabilme gibi beceri ve yeterlilikleri ifade etmişlerdir.

İlkokula başlayacak çocukların sahip olması gereken özellikler hakkında ebeveynler sosyal duygusal gelişimden sonra öz bakım becerileri, fiziksel ve motor gelişim, bilişsel gelişim ve dil gelişimi ile ilgili özellikleri belirtmişlerdir. Kodlar incelendiğinde öz bakım becerilerinde en çok tuvalet ihtiyacını kendi başına karşılayabilme, kendi temizliğini yapabilme ve tuvalet alışkanlığı kazanmış olma gibi özellikler vurgulanmıştır. Kendi başına kıyafetlerini giyebilme, yemek yiyebilme ve kişisel bakımını yapabilme de ifade edilen diğer becerilerdir.

Fiziksel ve motor gelişim temasına ait kodlar incelendiğinde yaşına uygun bedensel gelişime sahip olma ve kalem tutabilme özelliklerinin daha çok ifade edildiği belirlenmiştir. Kesme-yapıştırma yapabilme, küçük kasların gelişmiş olması, el becerilerinin gelişmiş olması, el kol kaslarını kullanabilme ve sağlıklı olma da belirtilen diğer özelliklerdir. Bilişsel gelişime ait kodlar incelendiğinde öğrenmeye açık olma, alg1 yeteneğinin gelişmiş olması, okul ile ilgili bilgiye sahip olma özelliklerinin daha çok belirtildiği okula gidiş amac1nı bilme, anlatılanı anlayabilme, dikkatini toparlayabilme ve yönergelere uyabilme özelliklerinin de ifade edildiği belirlenmiştir. Tablo 2 incelendiğinde dil gelişiminde ise kendini ifade edebilme ve iletişim becerilerine sahip olma ve yaşına uygun dil gelişimi gösterebilme özelliklerinin ifade edildiği görülmüştür. Ebeveyn görüşlerinden bazı örnekler aşağıda sunulmuştur:

"Kendini anlatabilmeli, kendi kendine tuvalet ihtiyacını giderebilmeli, toplum kurallarına uyabilmeli, öğrenmeye açı olup her şeyi öğrenme becerisine sahip olmal, verilenleri hemen alglamal, arkadaşlart ile iyi geçinebilmeli, toplumun uyulması gereken kurallarını öğrenmeye müsait olmall.” (E13)

“Çocuğun fiziksel ve dil gelişimi yaşına uygun düzeyde olmall, tuvalet 
alışkanlığı kazanmış olmalı, kendini ifade edebilmeli, öz güveni gelişmiş olmalı, anne babadan ayrı kalabilmeli, okula gidiş amacını bilmeli." (E8)

"Kendi kendine tuvalet ihtiyacını giderebilmeli, kıyafetlerini giyebilmeli, kendi yemek yiyebilmeli ve kalem tutabilmeli." (E1)

“Tuvalet, yemek yeme, giyinme gibi günlük ihtiyaçlarını karşılamalıdır. Iletişime açık hâle gelmelidir. Algl yeteneği gelişmiş olmalıdır.” (E11)

“Kalem tutma, kesip yapıştırma vs. becerileri yeterli olmall. Kendisini yeterince ifade edebilmeli." (E3)

\section{Okula Uyum Süreci}

$\mathrm{Bu}$ başl1k altında ebeveynlerin okula uyum sürecinde çocuklarda göZlenen davranışlar, okula uyum sürecinde okul yönetimi ve öğretmenin yaptıkları çalışmalar ve okula uyum sürecinin sağlıklı atlatılabilmesi için önerilere ilişkin bulgulara yer verilmiştir.

\section{Okula Uyum Sürecinde Çocuklarda Gözlenen Davranışlar}

Okula uyum sürecinde çocuklarda gözlenen davranışlar olumlu ve olumsuz olmak üzere iki tema altında toplanmıştır. Bu doğrultuda ebeveyn görüşlerine Tablo 3'te yer verilmiştir.

Tablo 3. Okula Uyum Sürecinde Çocuklarda Gözlenen Davranışlar

\begin{tabular}{ll}
\hline Tema & Kod \\
\hline Olumsuz Davranışlar & Anneyi yanında isteme \\
& Okula gitmede isteksizlik \\
Tuvalete gitmek istememe \\
Tedirginlik, korku \\
Ödev yapmada isteksizlik \\
Sinıf ortamına alışamama \\
Argo kelimeler kullanma \\
Çığlık atma \\
\hline Paylaşma \\
Kendini ifade etme \\
İletişim \\
Düzenli (kurallı) hareket etme \\
Arkadaş edinme \\
Öz güven \\
Sorumluluk \\
Tek başına tuvalete gitme \\
\hline
\end{tabular}

“Okula uyum sürecinde çocuğunuzda nasıl davranışlar gözlediniz?” sorusuna verilen yanıtlar incelendiğinde ebeveynlerin yarısı çocuklarında gör- 
dükleri farklı olumsuz davranışları ifade ederken yarısı da herhangi bir olumsuz davranış gözlemlemediklerini, çocuklarının okula kolay uyum sağladıklarını ifade etmişlerdir. Ebeveynlerin okula uyum sürecinde gözlenen olumsuz davranışlar temasında çoğunluğunun anneyi yanında isteme, okula gitmede isteksizlik, okulda tuvalete gitmek istememe, tedirginlik ve korku davranışlarını belirttikleri görülmektedir. Ayrıca bazı ebeveynler de çocuklarının ödev yapmada isteksizlik, sınıf ortamına alışamama, argo kelimeler kullanma ve çığlık atma davranışı gösterdiklerini ifade etmişlerdir. Okula uyum sürecinde gözlenen olumlu davranışlar temasında ise ebeveynlerin çocukların okula uyum sürecinde en çok paylaşma, kendini ifade etme, iletişim ve düzenli hareket etme konularında olumlu davranışlar gösterdiklerini belirtmişlerdir. Ebeveynlerin bir kısmı da çocuklarında "arkadaş edinme, öz güven, sorumluluk, tek başına tuvalete gitme ve kendini büyümüş hissetme" konularında olumlu davranışlar sergilediklerini ifade etmişlerdir. Ebeveyn ifadelerinden bazı örnekler aşağıda sunulmuştur:

"Kendi yapısı içe dönük ve utangaç olduğundan bir süre okulda beni yaninda istedi. Tedirgin oldu. Onunla okulda kalmak zorunda kaldım. Çocukların hareketliliği onu etkiledi. Onun için ortam soğuk ve mutsuz edici idi. Anaokulundan sonra siralara oturmak zor geldi." (E9)

"Okula başladiktan sonra akşam yatma ve sabah kalkma saatlerinde düzenli davranmaya başladı. Fakat okulda tuvalet sorunu yaşadık. Tuvaletlerin kalabalı olmasl ve temiz olmaması rahatsı etti. Bu yüzden tuvalete gitmek istemedi." (E17)

"Okula uyum sürecinde çocuğum okula çabuk alıştı. Sorun yaşamadl. Kalabalık bir ortamda kendini anlatabilme ve paylaşma duygusunu daha da güçlendirdi. Kendine öz güveni gelişti." (E6)

"Okulu çok sevdi. Daha kurallı oldu. Eve gelince geç kalma korkusuyla erken uyumak istedi. Sabahları kahvaltısinı heyecanla yapıp üzerini giyinmek istedi. Okuldan çıkınca arkadaşlarını anlatmaya başladı. Ama okuldaki çocukların bağırması, çı̆̆lık atmasından dolayı evde çı̆̆glı atmaya başladl." (E5)

\section{Okula Uyum Sürecinde Okul Yönetimi ve Öğretmenlerin Yaptık- ları Çalışmalar}

Okula uyum sürecinde okul yönetimi ve öğretmenlerin yaptıkları çalışmalar, çocuklara ve ailelere yönelik çalışmalar olmak üzere iki tema altında toplanmıştır. Bu doğrultuda katılımcıların görüsslerine Tablo 4'de yer verilmiştir. 
Tablo 4. Okula Uyum Sürecinde Okul Yönetimi ve Öğretmenlerin Yaptıkları Çalışmalar

\begin{tabular}{ll}
\hline Tema & Kod \\
\hline Çocuklara yönelik & Sanat etkinlikleri (Oyun hamuru oynama, resim yapma) \\
yapılan çalışmalar & Oyun etkinlikleri \\
& Okul tanıtımı \\
& Kuralların açıklanması \\
& Müzikle dans \\
\hline Ailelere yönelik & Veli toplantısı \\
yapılan çalış̧alar & Sınıf ve okul tanıtımı \\
& Tanışma etkinliği \\
\hline
\end{tabular}

"Okula uyum sürecinde okul yönetimi ve öğretmen ne tür çalışmalar yaptı?" araştırma sorusuna verilen yanıtlar incelendiğinde ebeveynlerin çoğunluğunun oyun hamuru oynama, resim yapma gibi sanat ve oyun etkinliklerinden, bir kısmının da okulun tanıtımına yönelik etkinliklerin yapıldığından söz ettikleri görülmüştür. Bazı ebeveynler de kuralların açıklandığını ve müzikle dans çalışması yapıldığını belirtmişlerdir. Ebeveynlerin bir kısmı da ailelere yönelik çalışmalar yapıldığından söz etmişler ve bunları da veli toplantısı, sınıf ve okul tanıtımı, tanışma etkinliği olarak sıralamışlardır. Ebeveyn görüşlerinden bazı örnekler aşağıda sunulmuştur:

"Okulumuz düzenli ve güzel. Öğretmenimiz çocukları okula alıştırmak için onların istediği şeyleri, oyun hamuru, resim, müzikle dans gibi şeyler yaptırıyordu. Kızım da okuluna çabuk alıştı. Öğretmenini sevdi." (E17)

"Müdür ve yardimciları tek tek sinıflarl gezerek kendilerini tanitıp okul hakkında bilgi verdiler. Hepsi de çok açıklayıcıydı. Öğretmenimiz çocuklara okulu gezdirip tanitt. Tuvalet ve kuralları, kantin, bahçe vs. Çocuklar üzerinde çok etkili oldu." (E12)

"Sinıf ve okul tanitımı yapıld. Veliler ile toplantı ve tanışma etkinliği yapıld. Sinıfa sadece öğrencileri alarak velilerin dışarda beklemesi istendi. Böylece ögretmen ile ögrrencilerin birbirlerine güven duymalar sağland.." (E15)

"Uyuma yönelik özel bir çalışma yapılmadı. Başlangıçta okul tanitıldl, oyun oynatıldı o kadar." (E9)

\section{Okula Uyum Sürecinin Sağlıklı Atlatılabilmesi İçin Öneriler}

Okula uyum sürecinin sağlıklı atlatılabilmesi için öneriler, öğretmenlere, ailelere ve okul yönetimine yönelik öneriler olmak üzere üç tema altında toplanmıştır. Bu doğrultuda katılımcıların görüşlerine Tablo 5 'te yer verilmiştir. 
Tablo 5. Okula Uyum Sürecinin Sağlıklı Atlatılabilmesi İçin Öneriler

\begin{tabular}{ll}
\hline Tema & Kod \\
\hline Öğretmenlere & Aile, öğretmen ve okul yönetiminin iş birliği içinde olması \\
yönelik öneriler & Çocukla ilgilenmesi \\
& Çocukla ilgili aile ile iletişime geçmesi \\
& Oyun, yarışma gibi etkinlikler yapması \\
& Oyunla, görsellerle dersi vermesi \\
& Aceleci olmaması \\
& Sakin olması \\
& Ilımlı olması \\
& Çocukların bireysel özelliklerine göre davranması \\
\hline Ailelere yönelik & Aile, öğretmen ve okul yönetiminin iş birliği içinde olması \\
& Çocuğa karşı sabırlı olması \\
& Çocuğa okulun önemini anlatması \\
& Çocuğa okul öncesi eğitim aldırılması \\
& Çocuğu yetiştirirken kuralların olması \\
& Çocuğun yanında okul hakkında olumsuz konuşmaması \\
& Çocuğa öz güven kazandırması \\
& Çocuğuna özel ilgi istememesi \\
& Çocuğun okula başlamasını abartmaması \\
\hline Okul yönetimine & Aile, öğretmen ve okul yönetiminin iş birliği içinde olması \\
yönelik öneriler & Uyum sorunları yaşayan çocuklara destek verilmesi \\
& Sinıflardaki öğrenci sayısının azaltılması \\
& Temizliğe önem verilmesi \\
& Sabırlı olunması \\
& Okulun cazip hâle getirilmesi
\end{tabular}

"Okula uyum sürecinin sağlıklı atlatılabilmesi için önerileriniz nelerdir?" araştırma sorusuna verilen yanıtlar incelendiğinde bütün temalarda aile, öğretmen ve okul yönetiminin iş birliği içinde olması cevabının öne çıktığı görülmüştür. Ebeveynler öğretmenlere iş birliği içinde olmaları, ilgili olmaları, çocukla ilgili aile ile iletişime geçmeleri, oyun, yarışma gibi etkinlikler yapmaları, oyunla ve görsellerle dersi vermeleri, aceleci davranmamaları, sakin ve 1lımlı olmaları ve çocuklara bireysel özelliklerine göre davranmaları gerektiği şeklinde önerilerde bulunmuşlardır. Ebeveynler ailelere yönelik önerilerini öğretmen ve okul yönetimiyle iş birliği yapma, çocuğa karşı sabırlı olma, çocuğa okulun önemini anlatma, okul öncesi eğitim aldırma, çocuğu yetiştirirken kurallar koyma, çocuğun yanında okul hakkında olumsuz konuşmama, çocuğa öz güven kazandırma, çocuğuna özel ilgi istememe ve çocuğun okula başlamasını abartmama olarak sıralamışlardır. Okul yönetimine yönelik önerilerini ise aile ve öğretmenle iş birliği yapılması, uyum sorunları yaşayan çocuklara destek verilmesi, sınıflardaki öğrenci sayısının azaltılması, temizliğe önem verilmesi, sabırlı olunması ve okulun cazip hâle getirilmesi olarak 
ifade etmişlerdir. Ebeveyn görüşlerinden bazı örnekler aşağıda sunulmuştur:

"Öncelikle çocuğun iletişsime açık olduğu her anda, ailelerin onu hazırlamasl, okula neden gitmesi gerektiğinin, bunun ne kadar önemli olduğunun anlatılması ve bu sürecin çocuk okula başladığında aynı șekilde bir süre devam etmesi gereklidir. Öğretmenler de çocuklara karşı ilgili olmallar, uyum sürecinde sadece resim değil de oyun, yarışma gibi başka aktiviteler yapabilirler." (E2)

"Uyum sürecinde aile, ögrretmen ve okul yönetimi iş birliği içerisinde olmall, yaşanan olumsuzluklart iş birliği içerisinde çözmeli, her çocuğun farklı olduğunu bilerek sabırlı olmalıdır." (E8)

"Uyum sürecinin sağllklı geçmesi için aileler önemli bir faktör. Çocuğa karşı sabırlı olmalılar. Okulun önemini çocuğa anlatmalılar. Öğretmen de aileyle iletişim içinde olmalı." (E18)

"Okulları katı kuralları olan bir yer olarak göstermemeliler. Aileler okulu çocuklara olumsuz anlatıyorlar. Çocuklara yalnız yaşayabileceklerini yani öz güveni aileler vermeli. Okul yönetimi de sorunlu çocuklara eğitim vermeli." (E20)

\section{Tartışma, Sonuç ve Öneriler}

$\mathrm{Bu}$ araştırmada çocukları ilkokula başlayan ebeveynlerin okula hazırbulunuşluk ve okula uyum süreci hakkındaki görüşlerini belirlemek amaçlanmıştır. Bu doğrultuda ebeveynlerin okula hazırbulunuşluğun tanımına ilişkin verdikleri cevaplar incelendiğinde okula hazırbulunuşluğu tanımlarken farklı gelişim alanlarına vurgu yapmakla birlikte çoğunluğunun sosyal duygusal alana atıfta bulundukları görülmektedir. Buldu ve $\operatorname{Er}(2016)$ tarafından yapılan çalışmada öğretmen ve ailelerin okula hazırbulunuşluğu tanımlarken çocukların sahip olduğu birçok beceri ve özelliği belirttikleri saptanmıştır. İlgili çalışmada katılımcılar okula hazırbulunuşluğu, çocuğun uyumsal yeteneklerinin olması (kişisel gelişim-başkasına muhtaç olmama), çocuğun istek, ihtiyaç ve düşüncelerini ifade edebilmesi, öğrenmeye karşı istekli olması ve yeni şeyleri merak etmesi olarak ifade etmişlerdir. Okula hazırbulunuşluk, çocuğun fiziksel, bilişsel, dil, sosyal ve duygusal gelişimi, öz bakım becerileri alanında ilkokula başlayacak yeterliliğe sahip olması, öğrenmeye karşı olumlu bir tutum geliştirmesidir.

Ayrıca çalışmada okula hazırbulunuşluk hakkındaki görüşlerini anlamak amacıyla ebeveynlere ilkokula başlayacak çocukların hangi özelliklere sahip olması gerektiği sorulmuştur. Görüşler incelendiğinde ebeveynlerin ilkokula başlayacak çocuğun sahip olması gereken özellikler hakkında beş ayrı kategoride çok sayıda beceri ve yeterlik belirtmekle birlikte sosyal duygusal 
gelişim ile öz bakım becerilerini daha çok ifade ettikleri belirlenmiştir. Bu sonuç Koçyiğit (2009) tarafından yapılan araştırma ile paralellik göstermektedir. İlkokul birinci sınıfta görev yapan 14 öğretmen ve 13 ebeveyn ile yürütülen araştırma sonucunda öğretmenlerin ve ebeveynlerin ilköğretime hazırbulunuşlukta sosyal becerileri diğer becerilerden daha önemli buldukları belirlenmiştir. Dockett ve Perry (2002) de yaptıkları araştırmada ebeveynler ve öğretmenlerin okula hazırbulunuşlukta sosyal uyum, iletişim ve sosyal beceriler gibi uyum becerilerini vurgulamışlardır. Ahmetoğlu, Ercan ve Aral (2011) yaptıkları araştırma sonucunda sosyal gelişimle ilgili maddelerin çocukların ilköğretime başlamasında etkili olan etmenlerin başında geldiğini ifade etmişlerdir. Yeşil-Dağlı (2012) tarafindan yapılan çalışmada ise ana sınıfı ve ana okuluna devam eden 115 velinin çocuklarının okula başlayabilmesi için önemli buldukları özellikler araştırılmıştır. Çalışmanın bulgularına göre velilerin tamamına yakınının okula başlayabilmeleri için çocukların öz bakım becerilerini edinmelerini, istek ve ihtiyaçlarını ifade edebilmelerini önemli buldukları tespit edilmiştir. Bu çalışmaların aksine Boz (2004), Kwong (2006), Skeete (2006) ve Ülkü (2007) tarafindan yapılan araştırmalarda ebeveynlerin okula hazırbulunuşlukta akademik becerilerin sosyal becerilerden daha önemli olduğunu düşündükleri belirlenmiştir. Ortaya çıkan bu farklı sonucun araştırmaların çalışma gruplarındaki ebeveynlerin farklı sosyoekonomik, kültürel ve eğitim altyapılarına sahip olmaları sebebiyle okula hazırbulunuşluk hakkında değişen bilgi düzeyleri ve bakış açılarından kaynaklandığı söylenebilir.

Ebeveynlerin okula uyum sürecinde çocuklarında gözlemledikleri davranışlara yönelik görüşleri incelendiğinde olumsuz davranışlar temasında çoğunluğunun çocuklarında anneyi yanında isteme, okula gitmede isteksizlik, okulda tuvalete gitmek istememe, tedirginlik ve korku davranışlarını gözlemlediklerini belirttikleri görülmektedir. Ülkü (2007) tarafından yapılan çalışmada, çocuklarda okula başlarken en fazla görülen sorunun anne-babadan ayrılmak istememeleri olduğu belirlenmiştir. İlkokula başlamak farklı bir ortama geçiş olduğundan okul öncesi eğitim almış olsa bile çocuk için zor olabilir. Ortamın, öğretmenlerinin ve arkadaşlarının değişmesi çocukta stres meydana getirebilir (Güler, 2018). Bazı çocuklar rahat ve hızlı bir şekilde okula uyum sağlayabilirken bazılarıysa okula uyum sürecinde zorlanabilir (Baştuğ ve Hiğde, 2020) ve okula uyumunu etkileyen faktörlere bağlı olarak farklı olumsuz davranışlar sergileyebilirler. Okula uyum sürecinde çocukta gözlenen olumlu davranışlar temasında ise ebeveynlerin en çok çocuklarının paylaşma, 
kendini ifade etme, iletişim, düzenli hareket etme konularında olumlu davranışlar gösterdiklerini ifade ettikleri görülmektedir. Çocukların okula uyumlarını etkileyen birçok faktör bulunmaktadır (Correia ve Marques-Pinto, 2016; Gülay-Ogelman ve Erten-Sarıkaya, 2013; Oktay, 2018). Çalışmaya dâhil edilen ebeveynlerin çocuklarının daha önce farklı sürelerde okul öncesi eğitim almış olmaları, cinsiyetleri ve yaşları gibi bazı faktörlerin etkisi çocukların kolay bir şekilde okula uyum sağlamalarına yol açmış olabilir. Nitekim alanyazında okul öncesi eğitim ile cinsiyetin çocukların okula uyumların kolaylaştırdığını belirten birçok çalışma bulunmaktadır. Bu çalışmalar incelendiğinde okul öncesi eğitim alan çocukların almayanlara göre, kıların da erkeklere göre okula daha kolay uyum sağladıkları görülmüştür (Çökük, 2019; Gedik, 2015; Işıkoğlu-Erdoğan ve Şimşek, 2014; Sarp, 1995; Topçu, 2012; Yeşil, 2008; Y1lmaz, 2019; Yoleri ve Tanış, 2014).

Okula uyum sürecinde okul yönetimi ve öğretmenlerin yaptıkları çalışmalara yönelik cevaplar incelendiğinde ebeveynlerin çoğunluğunun okula uyum sürecinde çocuklara yönelik oyun hamuru oynama, resim yapma gibi sanat ve oyun etkinliklerinden, bir kısmının da okulun tanıtımına yönelik etkinliklerin yapıldığından söz ettikleri görülmektedir. Ebeveynlerin bazıları da ailelere yönelik çalışmalar yapıldığını ifade etmişler bunları da veli toplantısı, sınıf ve okul tanıtımı, tanışma etkinliği olarak sıralamışlardır. Çocukların ilkokula uyumunu kolaylaştırmak için ilkokul birinci sınıfta oryantasyon programları uygulanmalıdır. Bu programlar, çocukların kendilerini güven içinde, iyi hissedebilecekleri, hayatlarının ve gelişimlerinin bütününe hitap eden çalışmalardan oluşmalı ve olabildiğince okul öncesinden ilkokula geçişteki ders, derslik, teneffüs farklılı̆̆ının belirginliğini azaltmaya çalışmalıdır. Bunun için de ilkokul ortamında fiziksel düzenlemeler yapılmalı, oyun zamanı artırılmalı ve çocukların ihtiyaçları doğrultusunda okulun gezilmesi ya da dramatizasyon çalışmalarına yer verilmelidir (Akşin-Yavuz, 2019). Okula uyum sürecinde çocukların hem yeni girilen ortamı yani okulunu, arkadaşlarını ve öğretmenini tanımalarına hem de okula uyumunu sağlamaya yönelik çalışmalar yapılmalıdır (Taşçı ve Dikici-Sığırtmaç, 2014). Ülkemizde Millî Eğitim Bakanlığı Temel Eğitim Genel Müdürlüğü tarafından yayınlanan bir oryantasyon programı bulunmaktadır. Bu programda çocukların gelişimsel özellikleri ve ihtiyaçları dikkate alınarak okul yönetimi ve öğretmenler tarafından gerekli düzenlemelerin yapılması çocukların okula uyum süreçlerini hızlandıracaktır. 
Ebeveynlerin okula uyum sürecinin sağlıklı atlatılabilmesi için öğretmenlere, ailelere ve okul yönetimine farklı öneriler sundukları, bununla birlikte aile, öğretmen ve okul yönetiminin iş birliği içinde olması gerektiğini vurguladıkları görülmektedir. Çocukların okula uyum sağlayabilmeleri için ailelerin ve öğretmenlerin iş birliği içinde olmaları çok önemlidir (KöksalAkyol, 2019; Yıldırım Haciibrahimoğlu, 2017). Kochhar-Bryant (2008) bütün çocukların okula başladıklarında endişe duymalarını olası bir durum olarak görmekte ve bu nedenle geçiş sürecinde hem aile hem de çocuk açısından iletişim, iş birliği, koordinasyon ve alınan kararların önemine vurgu yapmaktadır. Ayrıca çoğu ebeveyn öğretmenlerin ilgili olması, çocukla ilgili aile ile iletişime geçmesi, oyun, yarışma gibi etkinlikler yapmas1, oyunla ve görsellerle dersi vermesi gibi öneriler sunmuşlardır. Bay ve Şimşek-Çetin (2014), Chan (2010), Yazıcı, Nazik-Kumbasar ve Akman (2017) çalışmalarında ailelerin oyun temelli bir program istediklerini belirlemişlerdir. Correia ve Marques-Pinto (2016) yaptıkları çalışma sonucunda ebeveynlerin birinci s1nıfa uyum sürecinde okulun genel işleyişini, öğretmenin özelliklerini ve yöntemini de vurguladıklarını ortaya koymuşlardır. Demirtaş-Zorbaz (2016) ise öğretmen öğrenci ilişkisinin okula uyumu doğrudan etkilediğini ifade etmiştir. Yoleri ve Tanış (2014) da okula uyum sürecinde öğretmenlerin önemli bir role sahip olduğunu, çocukların okula kolay uyum sağlayabilmeleri için öğretmenlerin çocuklar için özel faaliyetler yapmalarının önemli olduğunu belirtmişlerdir. Ayrıca ailelerle sağlıklı bir iletişim içinde olup onları bilgilendirmeleri gerektiğini de vurgulamışlardır. Ateş (2016) de birinci sınıf öğrencilerinin okula uyumlarında en önemli faktörün öğretmen ile öğrenciler arasındaki iletişim olduğunu ifade etmiştir.

Araştırma sonuçlarından yola çıkıldığında eğitimcilere, ebeveynlere ve araştırmacılara şu önerilerde bulunulabilir:

- Okul öncesi dönemde okula hazırbulunuşluğun ne demek olduğu, ilkokula başlayacak çocuğun sahip olması gereken özellikler hakkında anne baba eğitimi çalışmaları yapılmalıdır.

- Çocuğu ilkokula başlayan aileler okula uyum süreci hakkında bilgilendirilmeli ve desteklenmelidir.

- Millî Eğitim Bakanlığı tarafindan son yıllarda uygulanan Okula Uyum Programının çocukların ve ailelerin ihtiyaçları dikkate alınarak niteliği arttırılmalı, birinci sınıf öğretmenlerine bu konuda alan uzmanları tarafindan eğitimler verilmelidir. 
- İlkokula başlayan birinci sınıf öğrencilerinin okula uyum sürecini kolaylaştırmak ve hızlandırmak için okul aile iş birliği artırılmalıdır.

- Ebeveynler ve öğretmenlerle odak grup görüş̧me yönteminin kullanıldığı yeni çalışmalar yapılabilir.

\section{Kaynakça}

Ahmetoğlu, E., Ercan, Z. G. ve Aral, N. (2011). Annelerin okul öncesi eğitime devam eden çocuklarının okul olgunluğu hakkındaki görüşlerinin incelenmesi. $2^{\text {nd }} I n$ ternational Conference on New Trends in Education and Their Implications içinde (s.1158-1167). Uluslararası Antalya Üniversitesi ve Akdeniz Üniversitesi.

Akşin-Yavuz, E. (2019). İlkokula hazırbulunuşlukta aile, öğretmen ve okul ne yapmalı? Ö. Polat, (Ed.), Adım adım ilkokula başlamak okula uyum ve erken okuryazarlık eğitimi içinde (109-140). Ankara: Anı.

Ateş, E. Ş. (2016). Sinıf ögretmenlerinin ilkokul 1. sınıfa devam eden öğrencilerin okula uyumlarına ilişkin görüşleri (Ankara ili Çubuk ilçesi örneği). Yayımlanmamış yüksek lisans tezi, Gazi Üniversitesi Eğitim Bilimleri Enstitüsü.

Ayten, M. (2019). 1. sınıf öğrencilerinin sahip olmaları gereken yeterliliklerin sınıf öğretmenleri ve ebeveynlerin görüşleri çerçevesinde değerlendirilmesi. Turkish Studies, 14(4), 2089-2116.

Bağçeli-Kahraman, P. (2020). Yaşamın ilk yıllarında okula uyumu etkileyen unsurlar. H. G. Ogelman, (Ed.), Yaşamın ilk yıllarında okula uyum içinde (39-73). Ankara: Eğiten Kitap.

Baştuğ, M. ve Hiğde, A. (2020). İlkokul dönemi, temel özellikleri, ilkokul 1. sınıf programı. Ö. Polat, (Ed.), Adım adım ilkokula başlamak okula uyum ve erken okuryazarlık eğitimi içinde (83-107). Ankara: Anı.

Baughan, C. C. (2012). An examination of predictive factors related to school adjustment for children with disabilities transtioning into formal settings. Yayımlanmamış doktora tezi, The Graduate School of Clemson University.

Bay, N. D. ve Şimşek-Çetin, Ö. (2014). Anasınıfından ilkokula geçişte yaşanan sorunlar ve çözüm önerileri. The Journal of Academic Social Science Studies, 7(7), 163-190.

Boz, M. (2004). Altı yaş çocuklarının okula hazırbulunuşluk düzeylerinin veli ve öğretmen görüşleri yönünden incelenmesi. Yayımlanmamış yüksek lisans tezi, Hacettepe Üniversitesi Sağlık Bilimleri Enstitüsü.

Brooks-Gunn, J., Berlin, L. J. ve Fuligni, A. S. (2000). Early childhood intervention programs: What about the family? J. P. Shonkoff ve S. J. Meisels, (Ed.), Handbook of early childhood intervention içinde (549-588). New York: Cambridge University Press.

Doi: $10.1017 / \mathrm{CBO} 9780511529320.026$

Buldu, M. ve Er, S. (2016). Okula hazırbulunuşluk ve okula başlama yaşı: Türk öğretmen ve ailelerin yeni eğitim politikası üzerine görüş ve deneyimleri. Eğitim ve Bilim, 41(187), 97-114.

Chan, W. L. (2010). The transition from kindergarten to primary school, as experienced by teachers, parents and children in Hong Kong. Early Child Development and Care, 180(7), 973-993. 
Commodari, E. (2012). Preschool teacher attachment, school readiness and risk of learning difficulties. Early Childhood Research Quarterly, 28(1), 123-133.

Correia, K. ve Marques Pinto, A. (2016). Adaptation in the transition to school: perspectives of parents, preschool and primary school teachers. Educational Research, 58(3), 247-264.

Çeliktürk-Sezgin, Z. (2020). İlkokul birinci sınıf çocuklarının velisi olmak: Heyecan ve endişeyi dengeleyebilmek. Ĕ̌itimde Nitel Araştırmalar Dergisi, 8(1), 1-17.

Çökük, K. (2019). Farklı yaşlarda ilkokula başlayan öğrencilerin okula hazırbulunuşluk ve uyum sorunları. Yayımlanmamış yüksek lisans tezi, Van Yüzüncü Y1l Üniversitesi Eğitim Bilimleri Enstitüsü.

Demirtaş-Zorbaz, S. (2016). İlkokul birinci sınıf öğrencilerinin okula uyumu: Bir model testi. Yayımlanmamış doktora tezi, Hacettepe Üniversitesi Eğitim Bilimleri Enstitüsü.

Dinç, B. (2013). Okul öncesi eğitimden ilköğretime geçiş ve okul olgunluğu. F. Alisinanoğlu, (Ed.), Illkögretime hazırlı ve ilkögretim programları içinde (89116). Ankara: Pegem Akademi Yayıncılık.

Dockett, S. ve Perry, B. (2002, Nisan). Beliefs and expectations of parents, prior-toschool educators and school teachers as children start school. Annual Conference of Australian Association for Research in Education'da sunulan bildiri. http://www.leeds.ac.uk/educol/documents/00003324.html

Entwisle, D. R., Alexander, K. L. ve Olsen, L. S. (2005). First grade and educational attainment by age 22: A new story. American Journal of Sociology, 110(5), 1458-1502.

Erkan, S. (2011). Farklı sosyoekonomik düzeydeki ilköğretim birinci sınıf öğrencilerinin okula hazırbulunuşluklarının incelenmesi. Hacettepe Üniversitesi Ĕ̈itim Fakültesi Dergisi, 40, 186-197.

Forget-Dubois, N., Lemelin, J. P., Boivin, M., Dionne, G., Seguin, J. R., Vitaro, F. ve Tremblay, R. E. (2007). Predicting early school achievement with the EDI: A longitudinal population-based study. Early Education and Development, $18(3), 405-426$.

Gedik, S. (2015). Öğretmen algılarına göre 60-66 aylık çocuklarda okula uyumun incelenmesi (Fatih ilçesi örneği). Yayımlanmamış yüksek lisans tezi, Yeditepe Üniversitesi Sosyal Bilimler Enstitüsü.

Gülay-Ogelman, H. ve Erten-Sarıkaya, H. (2013). Okul öncesi eğitimi almış çocukların okula uyum düzeylerinin 5 ve 6 yaşta incelenmesi: İki yıllık boylamsal ça1ışma. The Journal of Academic Social Science Studies, 6(7), 417-434.

Güler, T. (2018). Okul öncesi eğitimden ilköğretime geçiş. İ. H. Diken, (Ed.), Erken çocukluk ĕgitimi içinde (459-480). Ankara: Pegem.

Işıkoğlu-Erdoğan, N. ve Şimşek, Z. C. (2014). Birinci sınıfa başlayan çocukların, velilerin ve öğretmenlerin okula uyumlarının incelenmesi. International Journal of New Trends in Arts, Sports \& Science Education, 3(2), 62-70.

Kochhar-Bryant, C. A. (2008). Collaboration and system coordination for students with special needs. Upper Saddle River, N.J: Pearson Merrill Prentice Hall.

Koçyiğit, S. (2009). Illköğretim birinci sını öğretmenlerinin ve ebeveynlerin görüşleri ışı̆̆ı̆da okula hazır bulunuşluk olgusu ve okul öncesi ĕgitime ilişkin sonuçları. Yayımlanmamış doktora tezi, Selçuk Üniversitesi Sosyal Bilimler Enstitüsü. 
Koçyiğit, S. ve Saban, A. (2014). Birinci sınıf öğretmenlerinin ve ebeveynlerin görüşlerine göre okula hazır bulunuşluk. Kuramsal Eğitimbilim Dergisi, 7(3), 322-341.

Köksal-Akyol, A. (2019, Ekim). Okul yaşamına ve okul süreçlerine uyum. 30. Uluslararası Eğitimde Yaratıcı Drama Kongresi’nde sunulan bildiri, Adana. https://dramacongress2019.cu.edu.tr

Kwong, C. L. Y. (2006). Taiwanese parents' and kindergarten teachers' expectations for children's school readiness skills, Unpublished PhD Thesis, University of Alabama. ProQuest Dissertations and Theses veri tabanından erişildi. (UMI No: 3253058)

Merriam, S. B. (2013). Nitel araştırma: desen ve uygulama için bir rehber (3. bask1dan Çeviri). (S. Turan, Çev. Ed.). Ankara: Nobel Yayın Dağıtım. (Orijinal çalışma basım tarihi 2009)

Miclea, M. ve Mihalca, L. (2007). A computerized platform for the assessment of school readiness. Romanian Association for Cognitive Science, 1, 83-90.

Oktay, A. (2018). Çocuğun yaşamında okul, okula hazırbulunuşluk, hazırbulunuşluğu etkileyen temel faktörler ve ilkokula hazırlığın boyutları. A. Oktay, (Ed.), $\dot{I} l$ kögretime hazırlık ve ilkögretim programları okula uyum ve erken okuryazarlık eğitimi içinde (1-22). Ankara: Pegem Akademi Yayıncılık.

Oktay, A. ve Unutkan, Ö. P. (2003). İlköğretime hazır oluş ve okul öncesi eğitimle karşılaştırılması. M. Sevinç, (Ed.), Erken çocuklukta gelişim ve eğitimde yeni yaklaşımlar içinde (145-155). Ankara: Morpa Kültür Yayınları.

Özaslan, H. (2020). Okula hazırbulunuşluk ve ilkokula hazırlık. G. Uludağ ve T. Durmuş, (Ed.), Erken okuryazarlık eğitimi içinde (1-24). Ankara: Nobel.

Polat, Ö. ve Atış-Akyol, N. (2019). Okula uyum ve ilkokula hazırbulunuşluk. Ö. Polat, (Ed.), Adım adım ilkokula başlamak okula uyum ve erken okuryazarlık eğitimi içinde (1-30). Ankara: Anı.

Sarp, N. (1995). Öğretmenlerin ilkokula başlayan çocuklarda gözledikleri sorunlar ve bu sorunlara yaklaşımları. Kriz Dergisi, 3(1-2), 129-132.

Skeete, T. D. (2006). School readiness and assessment of young children: implications for policy and practice, Unpublished $\mathrm{PhD}$ Thesis, The University of Texas. ProQuest Dissertations and Theses veri tabanından erişildi. (UMI No: 3217352).

Taşçı, N. ve Dikici-Sığırtmaç, A. (2014). Okula uyum haftasının okul öncesi öğretmenleri ve sınıf öğretmenleri açısından incelenmesi. Milli Eğitim Dergisi, 202, 101-116.

Teymurlu, C. (2019). Ilkokul öğrencilerinin okula uyumu ve yaşadıkları sorunlarla ilgili veli ve ögretmen görüşleri üzerine bir olgubilim çalışması. Yayımlanmamış yüksek lisans tezi, Marmara Üniversitesi Eğitim Bilimler Enstitüsü.

Topçu, Z. (2012). Okul öncesi ĕgitimin ilkögretim birinci sınıf ögrencilerinin okula uyum ve Türkçe dil becerilerine etkisi. Yayımlanmamış yüksek lisans tezi, Hacettepe Üniversitesi Sosyal Bilimler Enstitüsü.

UNICEF. (2012). School readiness: a conceptual framework. New York: United Nations Children's Fund.

Ülkü, B. (2007). Anasınıfi ve ilköğretim 1. sınıfa devam eden çocukların velileri ve ögretmenlerinin çocukların okul olgunluğu hakkındaki görüşlerinin incelen- 
mesi. Yayımlanmamış yüksek lisans tezi, Çukurova Üniversitesi Sosyal Bilimler Enstitüsü.

Yazıc1, D. N., Nazik-Kumbasar, A. ve Akman, B. (2017). Ailelerin gözünden okul öncesinden ilkokula geçişte yaşanan güçlükler ve çözüm önerileri. Ö. Demirel ve S. Dinçer, (Ed.), Eğitimde yenilikler ve nitelik arayışı içinde (447-458). Ankara: Pegem Akademi.

Yeşil, D. (2008). Okul öncesi ĕgitim almış ve almamış öğrencilerin okula uyumlarının karşılaştırılması. Yayımlanmamış yüksek lisans tezi, Yeditepe Üniversitesi Sosyal Bilimler Enstitüsü.

Yeşil-Dağlı, Ü. (2012). Çocukları okul öncesi eğitim kurumlarına devam eden velilerin ilkokula hazırbulunuşluk ile ilgili görüşleri. Ekev Akademi Dergisi, 52, 231243.

Yıldırım, A. ve Şimşek, H. (2011). Sosyal bilimlerde nitel araştırma yöntemleri. Ankara: Seçkin Yayıncılık.

Yıldırım-Haciibrahimoğlu, B. (2017). Erken çocukluk döneminde geçiş ve geçiş süreci. Hacettepe Üniversitesi Ĕ̈itim Bilimleri Enstitüsü Eğitim Araştırmaları Dergisi, 3(1), 14-36.

Y1lmaz, N. (2019). Ilkokul birinci sınıfa başlayan ögrencilere uygulanan okula uyum haftast ve uyumu etkileyen faktörlere ilişkin ögrretmen görüsşleri. Yayımlanmamış yüksek lisans tezi, Ondokuz Mayıs Üniversitesi Eğitim Bilimleri Enstitüsü.

Yoleri, S. ve Tanış, H. M. (2014). İlkokul birinci sınıf öğrencilerinin okula uyum düzeylerini etkileyen değişkenlerin incelenmesi. Karabük Üniversitesi Sosyal Bilimler Enstitüsü Dergisi, 4(2), 130-141. 